\title{
Sheltered preservation in Ordovician trilobites
}

\author{
Oldřich Fatka ${ }^{1}$, Petr Budil ${ }^{2}$, and Petr Kraft ${ }^{1}$ \\ ${ }^{1}$ Institute of Geology and Palaeontology, Faculty of Science, Charles University, Albertov 6, \\ Prague 2, 128 43, Czech Republic \\ ${ }^{2}$ Czech Geological Survey, Klárov 3, Prague 1, 118 21, Czech Republic
}

Correspondence: Oldřich Fatka (fatka@ natur.cuni.cz)

Received: 22 October 2020 - Revised: 24 March 2021 - Accepted: 30 March 2021 - Published: 28 June 2021

\begin{abstract}
Articulated holaspid specimens of Placoparia Hawle and Corda, 1847 and Eoharpes Raymond, 1905 entombed inside cephalopod conchs and under the remains of large illaenid, asaphid, cyclopygid and dalmanitid trilobites from the Middle Ordovician Šárka Formation of the Prague Basin (Czech Republic) are described and discussed. Two such samples were also found in the overlying Dobrotivá Formation of Middle/Late Ordovician age. Four articulated juvenile exoskeletons of Placoparia preserved under a cephalon of the cyclopygid trilobite Degamella Marek, 1961 represent the first record of shelter strategy of non-holaspid trilobites. The sheltered preservation of trilobites could be explained by a hiding behaviour associated with the danger of predation, storm disturbances, seeking for food or high vulnerability after moulting. It is obvious that Placoparia and Eoharpes deliberately entered the restricted space under skeletal parts of large trilobites or inside cephalopod conchs. These exceptional finds provide a new insight in the life strategy of some Ordovician benthic trilobites and are classified as cases of "frozen" behaviour.
\end{abstract}

\section{Introduction}

Hiding (cryptic) behaviour of trilobites has been documented from Cambrian to Carboniferous fossil associations (e.g. Brett, 1977; Chlupáč, 1996; Peder and Feist, 1998; Suzuki and Bergström, 1999; Davis et al., 2001; Chatterton et al., 2003; Chatterton and Fortey, 2008; Valent et al., 2008; Flick and Flick, 2009; Radwański et al., 2009; Rakociński, 2009; Fatka and Budil, 2014; Hsieh and Plotnick, 2020). Comparable behaviour was described also in Cambrian agnostids (Chatterton et al., 2003; Fatka et al., 2009; Fatka and Szabad, 2011; Fatka and Kozák, 2014). This specific type of defensive strategy is supposed to be triggered by an increasing predation pressure connected with hunting activities of lobopods, diverse arthropods, cephalopods and gnathostome fishes (e.g. Brett, 2003; Brett and Walker, 2002; Babcock, 2003). The articulated trilobite carcasses transported by currents can be deposited around the cephalopod shell, but it is unlikely that they would be washed into the body chamber (see Wani, 2007). Consequently, it is unlikely that the trilobite carcasses were washed into the cephalopod conchs.

In general, brachiopod and molluscan conchs and valves as well as trilobite exoskeletons show evidence of healed bite marks and peeling from the Cambrian onward, but with an increased frequency in the Devonian (Brett and Walker, 2002; cf. also Bambach, 1999; Klug et al., 2017).

In this contribution, we describe 16 examples with articulated specimens of two trilobite genera, namely the harpetid Eoharpes Raymond, 1905 and the pliomerid Placoparia Hawle and Corda, 1847, entombed under pygidial and cephalic shields of much larger asaphid and illaenid trilobites, as well as several specimens of both taxa preserved inside cephalopod shells. These natural assemblages were collected from siliceous nodules from the Middle to the lowermost Upper Ordovician dark shales of the Šárka and Dobrotivá formations (Oretanian to lowermost Berounian regional stages, middle Darriwilian to lowermost Sandbian) in the Prague Basin, Teplá-Barrandian Unit, Czech Republic (Figs. 1, 2).

\section{Geological setting and stratigraphic framework}

The Prague Basin existed from the Early Ordovician (Tremadocian) to the Middle Devonian (Givetian). Cambrian to Devonian strata of the Barrandian area, including the Šárka and Dobrotivá formations, belong to the well-known 

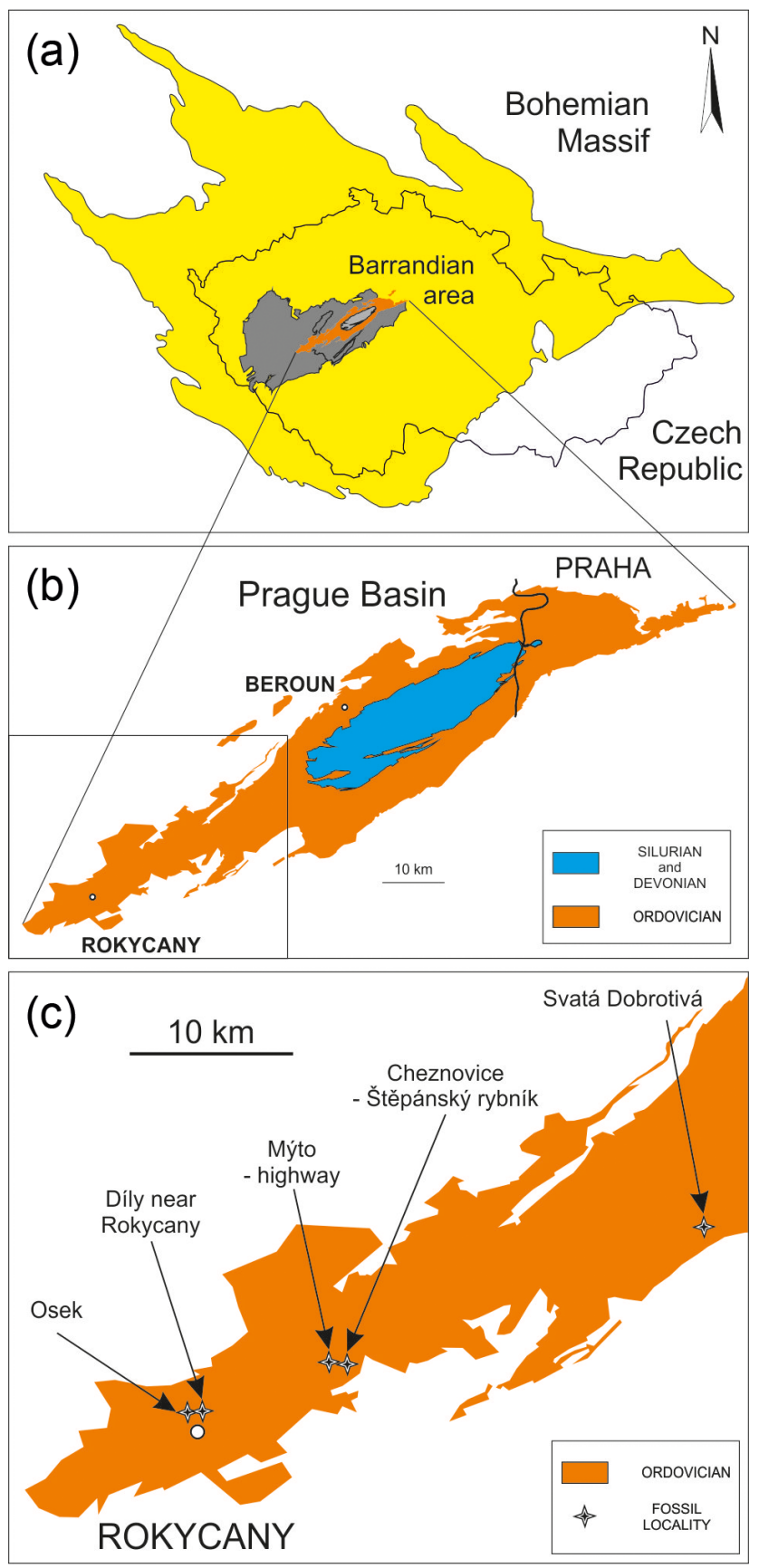

Figure 1. Geographical distribution of localities yielding Eoharpes and Placoparia preserved inside of cephalopod conchs and under large exoskeletal parts.

classical sections yielding a diverse marine fauna (e.g. Barrande, 1872; Bruthansová et al., 2007).

\subsection{Fauna of the Šárka and Dobrotivá formations}

The designation of the Šárka and Dobrotivá formations was proposed by Kettner and Kodym (1919). The former unit is represented by an up to $300 \mathrm{~m}$ thick sequence of grey to dark grey shale with sub-ordinate fine-grained siltstone. The thickness of the formation and amount of the coarsergrained admixture increase toward the eastern part of the basin. In the western and north-western parts, thick bodies of coeval volcanites and volcaniclastics belong to the Komárov Volcanic Centre (see Havlíček, 1998). Deposits of oolithic ironstones occurring in the Śárka Formation are related to the volcanic activity in that centre. Shale of the Šárka Formation locally contains numerous siliceous nodules with three-dimensionally preserved fossils, including trilobites. The overlying Dobrotivá Formation (late Darriwilian to lowermost Sandbian) is characterized by an up to $200 \mathrm{~m}$ thick rhythmical succession of quartzose sandstone (Skalka Quartzite) in its lower portion. Black shale with silty admixture and local greywacke (Dobrotivá Shale) overlay quartzose sandstone and dominate in the upper portion of the formation. The shale is of variable thickness (up to $350 \mathrm{~m}$ ) and also contains siliceous nodules, locally with fossils.

The concept of both formations was specified and modified especially by Havlíček and Vaněk (1966) and Havlíček (1998). General overviews of the stratigraphy and depositional settings of both units were given by Kukal (1962), Havlíček and Vaněk (1966), as well as Havlíček $(1982,1998)$. The Šárka Formation is subdivided into two graptolite biozones (in ascending order): Corymbograptus retroflexus and Didymograptus clavulus (Havlíček and Vaněk, 1966; Kraft and Kraft, 1999; Kraft et al., 2001). It was traditionally correlated with the British Llanvirn (e.g. Havlíček and Vaněk, 1966). Kraft and Kraft (1999) and Gutiérrez-Marco et al. (2017) correlated it with the Oretanian Regional Stage, which corresponds to the middle and late Darriwilian. The Dobrotivá Formation is also divided into two graptolite biozones: Hustedograptus teretiusculus and Cryptograptus aff. tricornis (for a summary see Kraft and Kraft, 1999). It is correlated with the late Darriwilian to lowermost Sandbian and corresponds to the Dobrotivian Regional Stage (Kraft and Kraft, 1999; Kraft et al., 2001; Gutiérrez-Marco et al., 2017).

\subsection{Fossil associations}

The well-diversified fauna of more than 200 species of trilobites, conulariids, bivalves, monoplacophorans, gastropods, hyoliths, ostracods, brachiopods, echinoderms, agnostids, phyllocarids, cephalopods, graptolites, and ichnofossils has been studied for more than 150 years (for an overview see Havlíček and Vaněk, 1966) in the Šárka Formation. Fossil associations of the Šárka Formation have been analysed by numerous authors; Fatka et al. (2015) briefly discussed earlier data and summarized the presence of the following faunal complexes: the Euorthisina-Placoparia Community, the "pelagic fauna dominated by graptolites", the Paterula Community Group, the stylophoran mitrocystitid and lagynocystitid biofacies, and transition from the Cruziana to the Zoophycos ichnofacies. More than 50 species of trilo- 


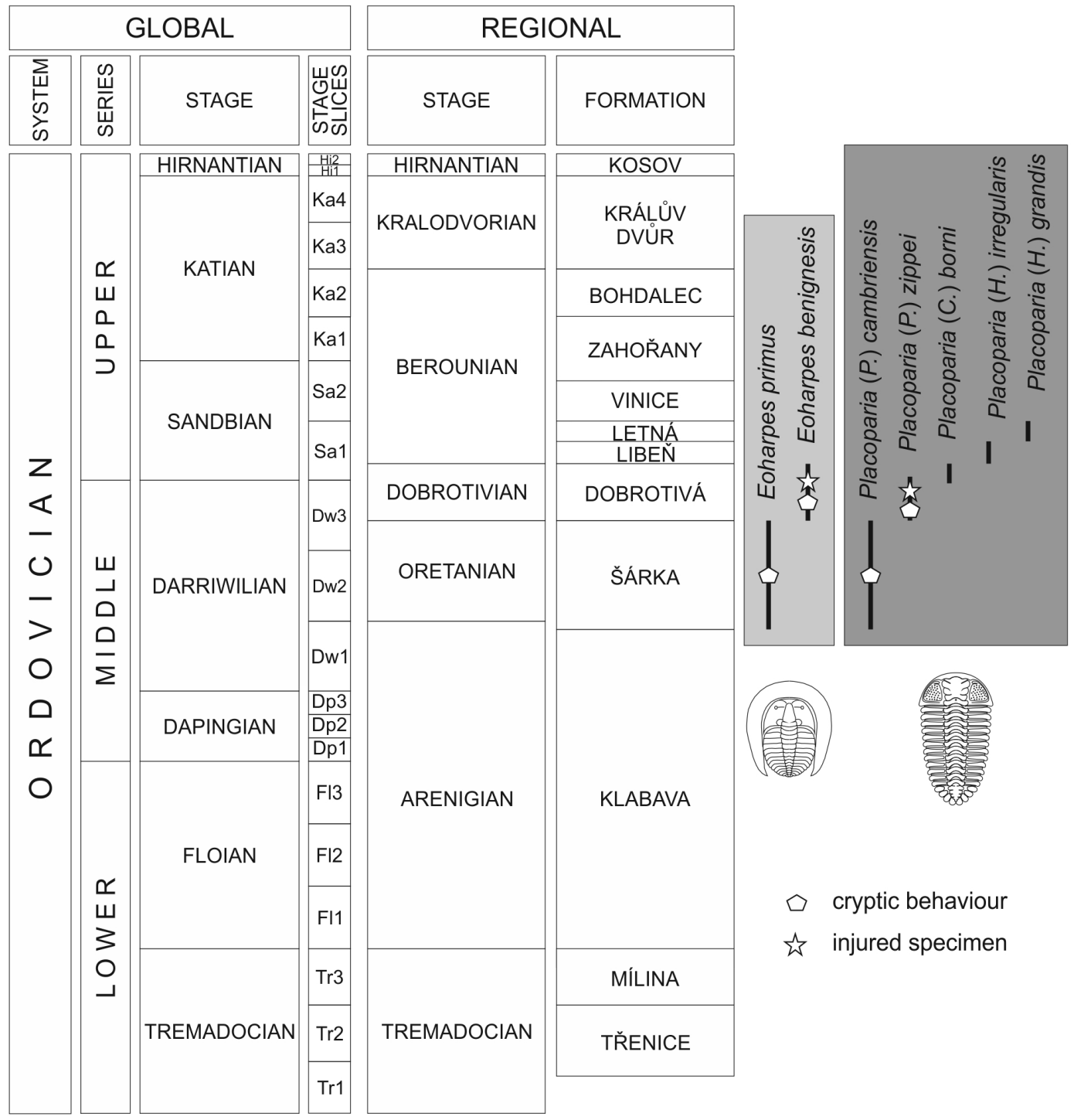

Figure 2. Stratigraphy of the Ordovician of the Prague Basin showing distribution of Eoharpes and Placoparia (modified from Fatka and Budil, 2014 and Budil and Fatka, 2021). Placoparia (P.) - Placoparia (Placoparia), Placoparia (C.) - Placoparia (Coplacoparia), Placoparia (H.) - Placoparia (Hawleia).

bites occur as dominant elements in these fossil associations (Havlíček and Vaněk, 1966; Budil et al., 2007; Mergl et al., 2007, 2008).

The shale of the Dobrotivá Formation locally contains a rich fauna, including 50 trilobite species (Mergl et al., 2008), sharing some similar features with the fauna of the Šárka Formation (most of genera persisted, several taxa disappeared/appeared). The fauna of the lower and middle portions of the Dobrotivá Shale is assigned mostly to the Placoparia Community or locally occurring DegamellaZeliszkella Assemblage; the deeper parts of the sedimentary basin belong to the Paterula Community Group with common cyclopygids (Mergl et al., 2008). The upper part of the formation yielded a different trilobite fauna containing Pla- coparia associated with Mytocephala Struve, 1958. Ichnofossils of the Dobrotivá Formation are similar to those of the Šárka Formation in some respects, such as a transitional character from the Cruziana to the Zoophycos ichnofacies in shales. In contrast, Skolithos Haldeman, 1840 is typical for the Skalka Quartzite, i.e. in the Dobrotivá Formation.

The trilobites of the Šárka and Dobrotivá formations can be assigned to the atheloptic association of deeper outer shelf environment (Fortey and Owens, 1987) and represent an example of the dalmanitid-calymenacean fauna of Cocks and Fortey (1988) like the illaenid-cheirurid community of Fortey (1975; see Bruthansová, 2003). They share numerous genera with Armorica and cratonic Gondwana, but trilobites 
from the Prague Basin belong to associations of a deeper, offshore character in general.

\subsection{Distribution and palaeoecology of Placoparia and Eoharpes}

Eoharpes Raymond, 1905 comprises six species, all restricted to the interval Darriwilian to lower Sandbian of West Gondwana (Fatka and Budil, 2014). The type species Eoharpes primus (Barrande, 1856) and E. benignensis (Barrande, 1872) are known from black-shale facies of the Šárka and Dobrotivá formations of the Prague Basin (Fig. 2); they belong to rare fossils in both units. Eoharpes has been classified as a filter-chamber feeding trilobite by Fortey and Owens (1999).

Placoparia Hawle and Corda, 1847 is one of the most common trilobites in the Middle Ordovician of the Prague Basin (Bruthansová and Budil, 2003). Fortey (1985) classified this genus, with some reservation, as an atheloptic trilobite. Although Owens and Servais (2007) supposed that Placoparia might have been epipelagic; especially the thick exoskeleton, natant hypostome and absence of eyes are generally considered as indicative of a benthic, partly buried, particle feeder (e.g. Hammann, 1971; Bruthansová and Budil, 2003). The sheltered preservation of some specimens of Placoparia described herein supports this interpretation.

\section{Material and methods}

Sixteen samples with articulated exoskeletons and disarticulated remains of the trilobite genera Placoparia and Eoharpes preserved inside or under skeletal parts of diverse invertebrates were studied. Six samples represent trilobite exoskeletons preserved inside of cephalopod conchs; five other samples include trilobite remains situated under cephalic and pygidial shields of large asaphid and illaenid trilobites.

Except for two samples, all herein studied trilobites come from the Šárka Formation and are preserved as threedimensional internal and external moulds in siliceous nodules; they were discovered in four localities in the southwestern part of the Prague Basin (Figs. 1, 2). Two of the studied specimens come from the slightly younger Dobrotivá Formation (VV 102, 172829a, b).

Specimens illustrated in this study are housed in the collections of the Czech Geological Survey Prague (VV 102, VV 285, VV 290, and VV 296a), Museum of West Bohemia in Plzeň (WBM S 05156, WBM S 157), Museum of Dr. B. Horák at Rokycany (specimen numbers MBHR 335, MBHR 337, MBHR 375, MBHR 382, MBHR 8948, MBHR 12 251, MBHR 21 086), Geological Survey of Austria in Vienna (GBA 2011/054/0001), and in the Schary Collection housed in the Museum of Comparative Zoology at Harvard University, Boston, Massachusetts, United States (MCZ 5136, 5137, 172829a, b). Four of the herein studied samples (VV 102, VV 285, VV 290, and VV 296a) were briefly discussed by Vokáč et al. $(2015,2019)$. Two specimens (MBHR 8948 and MBHR 12251) were collected by Jaroslav Kraft, and two specimens (MBHR 335 and MBHR 375) come from the old collection of Karel Holub. The last two samples (MBHR 21086 and WBM S 157) were most probably collected by the late Vratislav Kordule and were purchased by the Museum of West Bohemia in Plzeň in 2010 and 2013.

\section{Description}

\subsection{Placoparia and Eoharpes inside cephalopod conchs}

Six partly preserved internal moulds of middle-sized orthocone cephalopods contain eight articulated exoskeletons and one isolated cephalon of Placoparia as well as one fragment of Eoharpes. All trilobites are entombed inside chambers of cephalopod conchs in various orientations. As far as recognizable, all trilobites are holaspids. The dimension of one (Fig. $3 \mathrm{C}_{2}$ ) indicates a very early holaspid stage.

\section{Specimen MBHR 21086 (Fig. 3A, locality Osek)}

The short conch fragment of Endoceratida indet. without septa (probably a body chamber) is about $62 \mathrm{~mm}$ wide (this value is close to the conch diameter) and is of unknown orientation (apical and apertural directions are not clear). An internal mould of a slightly damaged articulated exoskeleton of Placoparia (Placoparia) cambriensis Hicks, 1875 is preserved inside the cephalopod fragment; the trilobite displays 12 thoracic segments and a partly preserved pygidium ( $p$ in Fig. 3A). Only the left postero-lateral part of the articulated, ventrally bent cephalon is exposed (c in Fig. 3A). The exposed trilobite remains are sagittally $14 \mathrm{~mm}$ long and up to $9 \mathrm{~mm}$ wide; its axis is oriented at an angle of about $30^{\circ}$ to the longitudinal cephalopod axis. The nearly straight thorax is slightly bent between the third and fifth segments. Such general configuration agrees well with the observation of Bruthansová and Budil (2003, p. 273, fig. 1A), who wrote that "the most common preservation pattern of complete Placoparia represent exoskeletons with straight thorax or slightly S-shaped, with the most abundantly the secondfourth thoracic segments convexly and cephalon slightly ventrally bent".

\section{Specimen WBM S 05156 (Fig. 3B, locality Cheznovice - Štěpánský rybník)}

This is a fragment of an indetermined pseudorthocerid body chamber, which is about $48 \mathrm{~mm}$ long and up to $27 \mathrm{~mm}$ in diameter. It has a finely annulated outer surface (Fig. $3 \mathrm{~B}_{1}$ ) and contains an internal mould of a complete articulated specimen of Placoparia sp., with all 12 thoracic segments. Only the left posterior part of cephalon and anterior part of the 


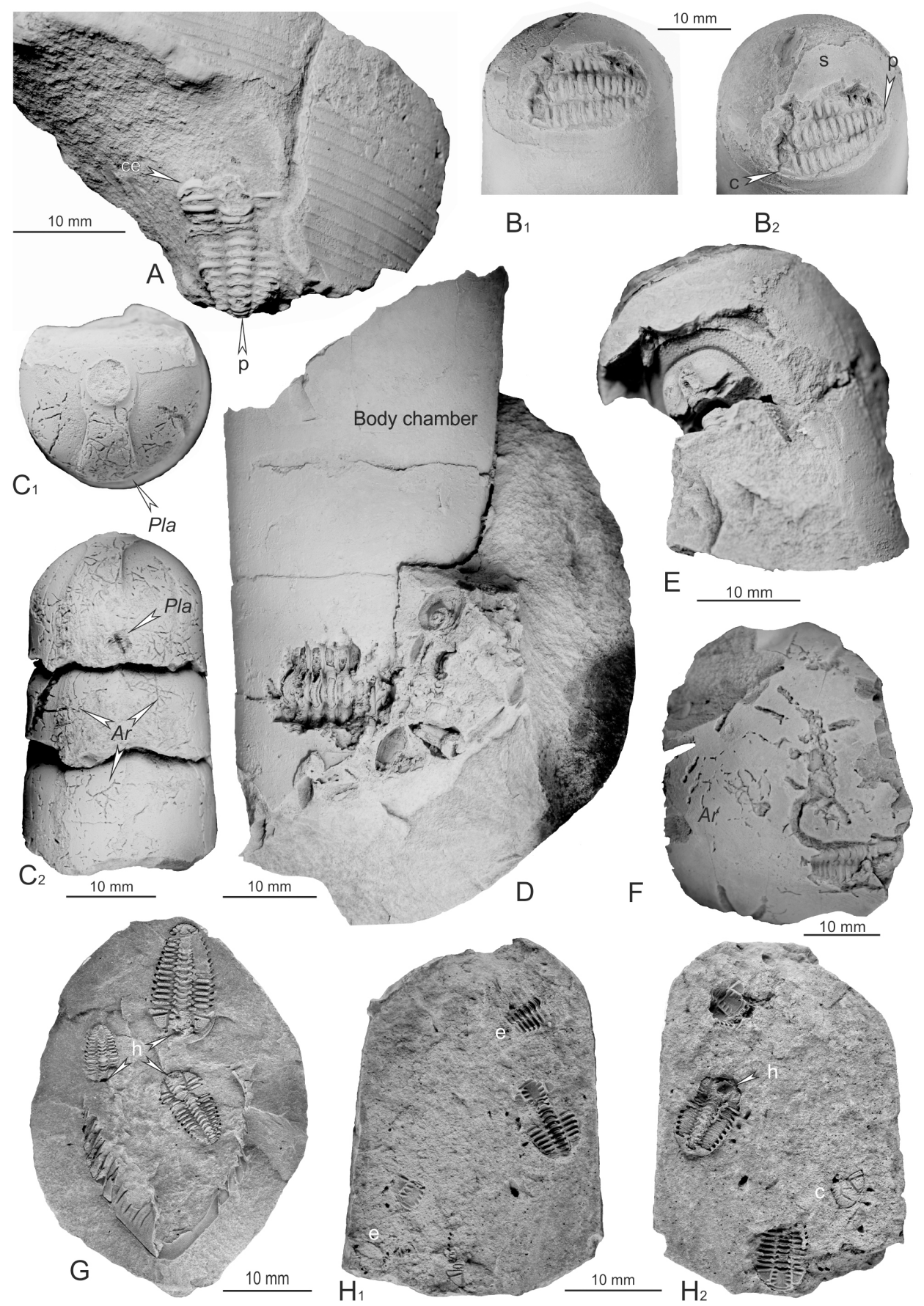

Figure 3. Sheltered trilobites from the Šárka Formation. (A) Internal mould of slightly damaged articulated exoskeleton of Placoparia sp. preserved inside of a cephalopod fragment, MBHR 21086. (B) Internal mould of a complete articulated specimen of Placoparia sp. preserved inside a fragment of an indetermined pseudorthocerid cephalopod, WBM S 05156. (C) External mould of thorax of a small trilobite ?Placoparia sp. preserved inside the phragmocone chamber of the rare actinocerid cephalopod "Orthoceras" cf. bonum Barrande, 1867, GBA 2011/054/0001. (D) Seven thoracic segments of Placoparia sp. preserved within an incomplete and indeterminable orthocone cephalopod, WBM S 157. (E) Internal mould of cephalon and axial part of two anterior-most thoracic segments of the harpetid trilobite Eoharpes sp. is preserved inside of an incomplete phragmocone chamber of a middle-sized undetermined cephalopod, MBHR 337. (F) Internal mould of articulated incomplete exoskeleton of Eoharpes primus preserved under a large shield of an illaenid or asaphid trilobite, MBHR 8948. (G) Internal moulds of three articulated holaspid exoskeletons of Placoparia associated with $25 \mathrm{~mm}$ long thoracopygon of a holaspid specimen of Ormathops atavus (Barrande, 1872), VV285. (H) Four articulated exoskeletons of Placoparia sp. inside of a body chamber of a small, undetermined cephalopod, VV296a, b. Ar-Arachnostega gastrochaenae, c - isolated cephalon of Placoparia, e - enrolled specimen of Placoparia, h - in situ preserved hypostome, p - pygidium, s - septum. Localities: (A) and (G) Osek, (B) Cheznovice - Štěpánský rybník, (D) Mýto - highway, (F) and (H) Díly near Rokycany, (C) and (E) unknown. All specimens coated with ammonium chloride. 
pygidium are exposed (ce and $\mathrm{p}$ in Fig. $3 \mathrm{~B}_{2}$ ); the right posterior part of the thorax is damaged. The trilobite exoskeleton lies close to the last formed septum separating the body and phragmocone chambers ( $\mathrm{s}$ in Fig. $3 \mathrm{~B}_{2}$ ); the exoskeleton is slightly dorsally bent to follow the curvature of the septum. The exposed part of the trilobite measures $14 \mathrm{~mm}$ in length; the complete specimen is estimated to reach $18 \mathrm{~mm}$ in length.

\section{Specimen GBA 2011/054/0001 (Fig. 3C, exact locality unknown, the character of the nodule points to Rokycany area in the south-western part of the Prague Basin)}

Three phragmocone chambers of the rare actinocerid cephalopod "Orthoceras" cf. bonum Barrande, 1867 are preserved as a loose, $38 \mathrm{~mm}$ long and between 18 and $23 \mathrm{~mm}$ in diameter measuring internal mould. Numerous tiny ichnofossils Arachnostega gastrochaenae Bertling, 1982 (Ar in Fig. $3 C$ ) are burrowed along internal surfaces of all chambers. External mould of the thorax of a small Placoparia sp. is seen inside the most proximal cephalopod chamber (Pla in Fig. $3 \mathrm{C}_{1}$ and $\mathrm{C}_{2}$ ).

\section{Specimen WBM S 157 (Fig. 3D, locality Mýto - highway)}

This is an internal mould of an incomplete and indeterminable orthoconic cephalopod, which is about $70 \mathrm{~mm}$ long and up to $30 \mathrm{~mm}$ in diameter. It consists of two complete and one incomplete phragmocone chambers associated with the posterior part of the body chamber. The internal mould of seven thoracic segments of Placoparia sp. are visible inside of the second and third phragmocone chambers; outside of the cephalopod conch, external moulds of at least two bivalves of Pseudocyrtodonta sp. and one bellerophontid gastropod, either Gamadiscus or Tropidodiscus, are visible.

Specimen MBHR 337 (Fig. 3E, exact locality unknown, the nodule comes from the old collection in the MBHR, which contains material originating from the Rokycany area in south-western part of the Prague Basin)

The internal mould of a cephalon and the axial part of two anterior-most thoracic segments of the harpetid trilobite Eoharpes sp. is preserved within an incomplete phragmocone chamber of a middle-sized undetermined cephalopod. The preserved part of the cephalopod measures $34 \mathrm{~mm}$ in length; the trilobite cephalon is $7 \mathrm{~mm}$ long.

\section{Specimen VV296a, b (Fig. 3H, locality Díly near Rokycany)}

The internal mould of the body chamber of a small, undetermined cephalopod contains one isolated cephalon (c in Fig. $\left.3 \mathrm{H}_{2}\right)$ associated with four articulated exoskeletons of Placoparia $(P$.) cambriensis; two of them are in a prone position, while the other two are enrolled (e in Fig. $3 \mathrm{H}_{1}$ ). All specimens of Placoparia are of about the same sagittal length ranging around $10 \mathrm{~mm}$; one of the straight exoskeletons has the hypostome preserved in situ (h in Fig. $3 \mathrm{H}_{2}$ ). This sample was originally briefly described and figured by Vokáč et al. (2019, p. 71, pl. 3, figs. 1-3).

\subsection{Placoparia and Eoharpes under remains of large trilobites}

Eight articulated exoskeletons of Placoparia, three complete articulated specimens and two disarticulated remains of $E O$ harpes are described, which are situated under pygidial or cephalic shields of large asaphid, illaenid, cyclopygid trilobites, and the under-articulated remains of a dalmanitid trilobite. It is significant that all trilobites are holaspids of variable sizes with a single exception of an association of four juveniles (Fig. 4F).

\section{Specimen MBHR 8948 (Fig. 3F, locality Díly near Rokycany)}

Partly exposed internal mould of an articulated incomplete exoskeleton of Eoharpes primus was preserved under the remains of a large shield of an illaenid or asaphid trilobite. Both fossils have the same convex (dorso-ventral) orientation. Fine ramified burrows of Arachnostega gastrochaenae are developed on the internal surface of the pygidium ( $A r$ in Fig. 3F). A wide linear, looped burrow is preserved in the central part of the large shield fragment; this Palaeophycuslike trace crosses the space between the articulated trilobite exoskeleton and the cover shield and changes its direction at the surface of the large shield.

\section{Specimen VV285 (Fig. 3G, locality Osek)}

Internal moulds of three articulated exoskeletons of Placoparia $(P$.) cambriensis are associated with a $25 \mathrm{~mm}$ long thoracopygon of Ormathops atavus (Barrande, 1872); all Placoparia remains have a roughly in situ preserved hypostome (h in Fig. 3G). They are of the same dorso-ventral orientation together with Ormathops and lie approximately on the same plane. Two smaller specimens of Placoparia, 7.0 and $9.5 \mathrm{~mm}$ long sagittally, are situated under the thoracopygon. The largest specimen measures $14.5 \mathrm{~mm}$ sagittally and is placed at least partially outside of the thoracopygon. Two specimens of Placoparia and Ormathops are oriented with almost parallel sagittal axes; one Placoparia is oriented slightly oblique. However, the overall direction of all trilobites is very similar; only two specimens of Placoparia near the anterior end of the damaged Ormathops are situated opposite of the third Placoparia and Ormathops itself. The sizes, orientation and placement apparently follow the vaulting of the covering exoskeleton. This sample was originally briefly described and figured by Vokáč et al. (2019, p. 71, pl. 3, figs. 4, 5). 


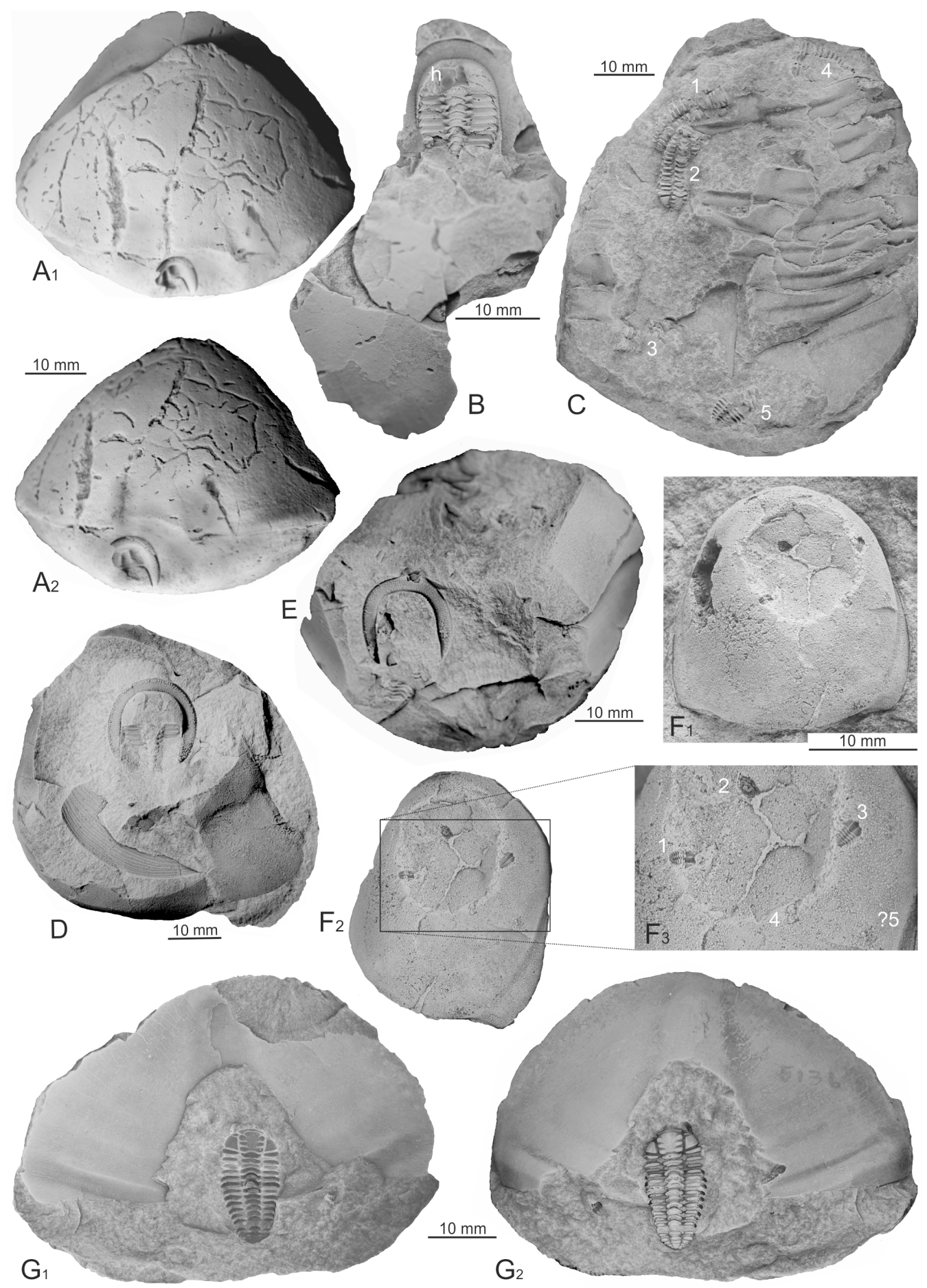

Figure 4. Sheltered trilobites from the Šárka and Dobrotivá formations. (A) Isolated cephalon of Eoharpes preserved upside-down under a comparatively large pygidium of Ectillaenus katzeri katzeri, MBHR 382. (B) Internal mould of Eoharpes primus preserved under a large, effaced pygidial or cephalic shield of an indeterminable asaphid or illaenid trilobite, MBHR 375. (C) Internal and external moulds of holaspid exoskeletons of Placoparia (P.) cambriensis preserved associated with the exoskeletal parts of Asaphellus desideratus, VV 290. (D) Internal mould of articulated exoskeleton of Eoharpes primus preserved under a large shield of an indeterminable asaphid or illaenid trilobite, MBHR 12251. (E) Disarticulated exoskeleton of Eoharpes primus under a large shield of an indeterminable trilobite, MBHR 335. (F) External moulds of four juvenile specimens of Placoparia sp. preserved inside an internal mould of a cranidium of an isolated cephalon of Degamella princeps, VV 102. (G) Complete articulated exoskeleton of Placoparia (P.) cambriensis preserved under the anterior part of an isolated pygidium of Asaphelus desideratus, MCZ 5136 and 5137. Ar-Arachnostega gastrochaenae. Localities: (B) Díly near Rokycany, (C)-(E) Osek, (A), (F), and (G) unknown. All specimens coated with ammonium chloride. 
Specimen MBHR 382 (Fig. 4A, exact locality unknown, the nodule comes from the old collection in the MBHR, which contains material originating from the Rokycany area in south-western part of the Prague Basin)

A small external mould of an isolated cephalon of Eoharpes is preserved under the anterior edge of a large pygidium of Ectillaenus katzeri katzeri (Barrande, 1872). The pygidial internal surface is disturbed by ramified burrows of Arachnostega gastrochaenae and wider, simple burrows of Palaeophycus sp.

\section{Specimen MBHR 375 (Fig. 4B, locality Díly near Rokycany)}

A well-preserved internal mould of Eoharpes primus is visible under a large, effaced pygidial or cephalic shield of an indeterminable asaphid or illaenid trilobite. The exoskeleton of $E$. primus includes the cephalon articulated with at least 10 thoracic segments; the posterior-most segments of thorax and pygidium are not exposed. The external surface of the slightly sinistrally dislocated hypostome is preserved under the broken glabella (h in Fig. 4B). Small rests of burrows are preserved along the internal mould of the cover shield.

\section{Specimen VV 290 (Fig. 4C, locality Osek)}

Five specimens of Placoparia $(P$.) cambriensis are preserved together with an internal mould of dissociated parts of the exoskeleton of Asaphellus desideratus (Barrande, 1872). Two articulated exoskeletons of Placoparia are situated close to each other, and three incomplete exoskeletons are randomly distributed and oriented. The articulated specimens and one incomplete exoskeleton share the same convex-upward orientation with the asaphid trilobite (internal moulds 1-3 in Fig. 4C), while the other two incomplete specimens are oriented opposite, i.e. concave-upward orientation (external moulds 4 and 5 in Fig. 4C). All specimens of Placoparia display a random orientation with respect to their sagittal axes. Their length varies around $14 \mathrm{~mm}$. This sample was originally briefly described and figured by Vokáč et al. (2015, p. 72, pl. 3, fig. 6).

\section{Specimen MBHR 12251 (Fig. 4D, locality Osek)}

A partly exposed and slightly damaged internal mould of the articulated exoskeleton of Eoharpes primus is preserved under a large broken cephalic shield of Ectillaenus sp. with dislocated doublure. The exoskeleton of E. primus is $15 \mathrm{~mm}$ wide and is located under the most vaulted central region of the illaenid cephalon with its anterior facing the posterodextral edge of the cover shield fragment and identical dor$\mathrm{sal} /$ ventral orientation.

\section{Specimen MBHR 335 (Fig. 4E, locality Osek)}

A fragmentary exoskeleton of Eoharpes primus includes the external mould of the ventral side of the brim and partly preserved internal moulds of at least five articulated thoracic segments separated from the cephalon and shifted posteriorly left. Remains of E. primus are situated under a large cephalic or pygidial shield of an indeterminable trilobite.

\section{Specimen VV 102 (Fig. 4F $1-F_{3}$, locality Osek)}

Four external moulds of juvenile specimens of Placoparia sp. are distributed along a slightly damaged internal mould of a large cranidium of the cyclopygid Degamella princeps (Barrande, 1872) in its anterior part, under the slightly cracked part of the exoskeleton. Two of them are stretched out, and the other two specimens are enrolled; their orientation to each other with respect to the cyclopygid cephalon is random. The best preserved exoskeleton measures about $1.2 \mathrm{~mm}$ in length and displays at least six thoracic segments. This sample was originally briefly described and figured by Vokáč et al. (2015, p. 71, pl. 2, figs. 1-5) and represents the first occurrence of remains of articulated juvenile trilobite sheltered preservation.

\section{Specimen MCZ 5136 and 5137 (Fig. 4G $1, G_{2}$, exact locality unknown)}

A complete articulated exoskeleton of Placoparia (P.) cambriensis is preserved partly entombed under the anterior, wider part of a pygidial axis of an isolated pygidium of the asaphid trilobite Asaphellus desideratus. The specimen of $P$. (P.) cambriensis is situated close to the internal surface of the moderately vaulted pygidium inside its most vaulted axial lobe, oriented with its sagittal axes almost parallel to each other and its anterior facing the posterior margin of the large shield. The isolated pygidium is $73 \mathrm{~mm}$ long; the exoskeleton of Placoparia measures $15 \mathrm{~mm}$ in sagittal length.

\section{Specimen MCZ 172829a and MCZ 172829b (locality Sancta Benigna = Svatá Dobrotivá (part of Zaječov), probably Kozojedská štola (former gallery))}

Fatka and Budil (2014) described six specimens of the harpetid Eoharpes benignensis entombed under a pygidial shield of the large asaphid trilobite Nobiliasaphus repulsus Přibyl and Vaněk, 1968, concluding that these trilobites produced a gregarious cluster inside a hidden cavity under the skeletal remains of a much larger trilobite, in a way similar to Placoparia reported by Gutiérrez-Marco et al. (2009). 


\section{Discussion}

\subsection{General background for understanding observations}

Predator-prey interactions in the early Paleozoic are rarely preserved and thus poorly understood (e.g. Brett and Walker, 2002; Kelly et al., 2003). However, it is generally accepted that trilobites played an important role both as predators and as nutritious prey (Fortey and Owens, 1999; Babcock, 2003). Like other invertebrates, Ordovician trilobites were in danger of being attacked by diverse predators like cephalopods and large arthropods such as chelicerates and phyllocarids (Brett and Walker, 2002; Fatka et al., 2021a, b). In the Barrandian area, the Ordovician record of injured skeletal invertebrates includes gastropods, cephalopods and trilobites (summary in Fatka et al., 2021a). The injuries of gastropods were ascribed to cephalopods, echinoderms and arthropods (Horný, 1997a, b). Similarly, the injuries of cephalopods were interpreted to be produced by other cephalopods by Aubrechtová (2015) and Aubrechtová and Turek (2018).

Remains of large non-trilobite arthropods have not been found, while middle-sized cephalopods are relatively common in the Šárka and Dobrotivá formations (Havlíček and Vaněk, 1966). Consequently, the life strategy of cephalopods and their position in Ordovician ecosystem is to be discussed, as they are potential culprits.

\subsection{Role of cephalopods}

Recent cephalopods are active carnivorous predators with only a few exceptions (Fernández-Álvarez et al., 2018). Similarly, fossil cephalopods have been considered carnivorous (Nixon, 1988). Large cephalopods were abundant in marine assemblages from the Lower Ordovician onward (e.g. Brett and Walker, 2002; Kröger, 2011), including the Barrandian area (Manda, 2008; Aubrechtová, 2015; Aubrechtová and Turek, 2018). However, their capability to break shells cannot be proven due to the lack of direct evidence of jaws, but they appeared supposedly in the Ordovician (Klug et al., 2017).

\subsection{Injured Middle-Late Ordovician trilobites in the Prague Basin}

The record of trilobites showing exoskeletal changes interpreted as healed injuries after failed attacks includes seven published examples; two of them come from the middle to late Darriwilian Šárka Formation. Marek (1961, pl. 2, fig. 8), Kraft (1972, pl. 3, fig. 6) and Bruthansová (2004, text fig. 8G) figured an anomalous visual surface of the eye of the cyclopygid Pricyclopyge binodosa binodosa (Salter, 1859). Comparable injuries of eyes in Middle Ordovician trilobites were interpreted as failed predation attempts by a cephalopod (Schoenemann et al., 2017). Budil et al. (2010) described articulated specimens of the rare Areiaspis barrandei (Novák in Perner, 1918) with a shortened distal tip of the left pleura; the authors wonder whether the injury resulted from a predatory attack and/or originated during the moulting process.

The other six injured trilobites were collected at localities of the overlying late Darriwilian-early Sandbian Dobrotivá Formation. Prantl and Přibyl (1954, pl. 10, fig. 3) figured a well-preserved internal mould of an articulated young specimen of the harpetid Eoharpes benignensis with an anomalous right brim margin. Šnajdr (1979) described three anomalous exoskeletons of the common pliomerid Placoparia zippei (Boeck); two specimens show an anomalous development of the glabellar lobes, and the third articulated exoskeleton has anomalously developed third to fifth right thoracic pleurae. A partly enrolled exoskeleton of the nektobenthic trilobite Parabarrandia bohemica (Novák in Perner, 1918) with a healed abnormality on the pygidium was documented from the Dobrotivá Formation by Fatka et al. (2021a).

The above listed data about injured Ordovician trilobites in the Barrandian area demonstrate the following:

- Like other invertebrates, trilobites of the Šárka and Dobrotivá formations were in danger of predation.

- Cephalopods are usually considered to be responsible for most of the attacks although jaws are unknown in this group before the Silurian (Klug et al., 2017).

- Among the effective and obviously successful strategies to reduce the risk of predation, hiding inside or under skeletal remains has been utilized since Cambrian times (for a summary, see Klompmaker and Fraaije, 2012; Fatka and Budil, 2014).

\subsection{Shelter in Ordovician trilobites}

Davis et al. (2001) reported examples of Flexicalymene meeki (Foerse, 1910) and Acidaspis sp. preserved inside the cephalopod Treptoceras sp. from the Late Ordovician (Cincinnatian) of Cincinnati, Ohio (USA), and Isotelus gigas DeKay in an orthocone cephalopod from the Ordovician of Iowa (USA). Three examples of cryptic behaviour of Placoparia were documented from peri-Gondwanan Europe. Mikuláš and Slavičcová (2001) described Placoparia forming cryptic linear clusters from the locality Osek of the Šárka Formation. From the middle Darriwilian trilobite assemblage of the Valongo Formation of north-western Portugal, Gutiérrez-Marco et al. (2009, fig. 3C) figured and discussed a moult cluster of more than 18 articulated exuviae of Placoparia $(P$.$) cambriensis preserved under a carapace$ of the giant Ogyginus forteyi Rábano. This cryptic behaviour has been interpreted by Gutiérrez-Marco et al. (2009, p. 445) as a shelter from predation. Fatka and Budil (2014) described six specimens of the harpetid Eoharpes benignesis entombed under a pygidial shield of the large asaphid trilobite Nobiliasaphus repulsus. 


\subsection{Comments on observations and their possible causes: other scenarios}

Although the accidental formation of the above described associations can never be ruled out, typical repeating patterns exclusively in two trilobite genera, Placoparia and Eoharpes, give rise to quite likely explanations in the absence of hard evidence. They suggested a causal origin in the interactions of the living individuals of Placoparia and Eoharpes on the one hand and shell remains of dead large trilobites and empty cephalopods on the other hand.

Two complete articulated specimens of Placoparia are preserved inside diverse parts of cephalopod conchs (MBHR 21086 and WBM S 05156, Fig. 3A, B). They represent most probably carcasses rather than molts. Such exoskeletal configuration and the placement of both specimens agree well with the suspected lodging (cryptic behaviour associated with hiding from predators); feeding on remnants of the dead cephalopod is also possible.

In the sample GBA 2011/054/0001 (Fig. 3C), the enrolled small exoskeleton of Placoparia is associated with numerous burrowing traces of A. gastrochaenae, an ichnofossil interpreted as feeding trace (fodichnion; see Kraft et al., 2020) or a dwelling burrow (domichnion; see Bertling, 1982; Fatka et al., 2011; Vinn et al., 2014). Such a fossil association suggests that the producer of Arachnostega and Placoparia shared the remnants of the dead cephalopod, its decaying tissues, bacterial decomposers or their metabolites (Kraft et al., 2020). However, lodging or hiding from predators cannot be excluded. In any case, the size of Placoparia is significant because the trilobite had to reach the internal cavity of the chamber passing through the siphuncle.

Similarly, the complete, perfectly articulated exoskeleton of E. primus preserved under a large trilobite pygidium is also associated with numerous burrowing traces of A. gastrochaenae (MBHR 8948, Fig. 3F) and most probably preserves either feeding in shelter or lodging (hiding from predators).

The absence of a cephalic shield in Placoparia in the sample WBM S 157 (Fig. 3D) and the incomplete exoskeleton of Eoharpes in the sample MBHR 337 (Fig. 3E) give the impression of exuviation in a sheltered environment (Bruthansová and Budil, 2003; Bruthansová, 2004).

In the sample VV285 (Fig. 3G), three complete exoskeletons of Placoparia with hypostomes under cephalic shields reliably represent carcasses. Two smaller specimens are positioned entirely inside the cavity under the thoracopygon of Ormathops atavus (Barrande, 1872), while only the anterior part of the largest specimen lies inside this cavity. Such placement and orientation agree well with feeding in shelter. However, hiding from predators also could not be excluded.

A co-occurrence of an isolated cephalon together with both enrolled and straight exoskeletons of Placoparia observed in the sample VV296a, b (Fig. 3H) makes the expla- nation as exuviation in shelter and/or feeding on remnants of the cephalopod possible.

Remains of a disarticulated exoskeleton of Eoharpes (MBHR 335, Fig. 4E) and the isolated cephalon of Eoharpes (MBHR 382, Fig. 4A), both preserved under shields of large trilobites, can be attributed to the exuviation in shelter. However, due to the lack of other supporting observations, the origin especially of these two associations by a hydrodynamic concentration cannot be excluded.

The articulated exoskeleton of Eoharpes with hypostome (MBHR 375, Fig. 4B), the other articulated specimen of this genus (MBHR 12251, Fig. 4D), the complete Placoparia (MCZ 5136, 5137, Fig. 4G) and four external moulds of juvenile Placoparia (VV 102, Fig. 4F) preserved under large (relative to their dimensions) trilobite shields indicate either feeding in shelter or lodging (hiding from predators).

The distribution pattern of the internal and external moulds of five holaspid exoskeletons of Placoparia associated with disarticulated exoskeleton of Asaphellus desideratus (VV 290, Fig. 4C) can reflect feeding on decaying organic matter dispersed around the carcass of the large trilobite.

It is unlikely that the unimodal monotaxic aggregations of articulated exoskeletons of Placoparia and Eoharpes and the occurrence of individual specimens of these two genera under remains of larger trilobites or inside cephalopod conchs originated randomly. Trilobites deliberately entered shells of dead cephalopods for food, refuge, ecdysis, reproduction, lodging, etc. (e.g. Mikulic, 1994). Similar explanations could be supposed also for the above-described trilobites preserved under carapaces of large trilobites. The enrolment of several exoskeletons indicates that these trilobites were buried alive and likely enrolled in response to stress caused by rapid burial. Such an explanation was proposed and discussed by Brett et al. (2012) as Type I assemblage.

Remains of large trilobite exoskeletons and cephalopod conchs likely served as a shelter only when partly filled by sediment. The influx of sediment after entering the restricted space prevented leaving the shelter and buried the immobilized scene. Completely missing signs of fragmentation and abrasion, together with the high number of articulated specimens inside the shelter, suggest that these specimens are preserved due to a rapid burial with no or minimal pre-burial disturbance. Such a type of preservation could be explained by cryptic behaviour of Placoparia and Eoharpes.

The described examples from the Šárka and Dobrotivá formations are interpreted as hiding from predators, scavenging on remnants of carcasses, feeding in shelter and exuviation in shelter. Thus, they are considered to represent cases of "frozen" behaviour (sensu Boucot, 1990, and Boucot and Poinar, 2010). 


\section{Conclusion}

Fourteen samples from the Middle Ordovician Šárka Formation and two specimens from the overlying Dobrotivá Formation contain one to six trilobite exoskeletons preserved in the protected space inside of empty cephalopod conchs or under thorax, cephalic and pygidial shields of much larger disarticulated trilobites. Analyses of the level of articulation of trilobite exoskeletons in combination with their orientation, disposition, and placement makes it possible to conclude that the hidden trilobites deliberately entered shells of dead cephalopods for food, refuge, ecdysis, reproduction or lodging. The occurrence of four specimens of Placoparia preserved under the cephalon of the cyclopygid trilobite Degamella shows us for the first time the shelter strategy of juvenile ontogenetic stage. The herein described fossil associations are classified as cases of "frozen" behaviour.

Sample availability. Specimens discussed and illustrated in this study are housed in the collections of the following institutions: Czech Geological Survey Prague; Museum of West Bohemia in Plzeň; Museum of Dr. B. Horák at Rokycany; Geological Survey of Austria in Vienna; and in the Schary Collection housed in the Museum of Comparative Zoology at Harvard University, Boston, Massachusetts, United States.

Author contributions. OF prepared the figures and wrote the manuscript with contributions from both co-authors. PB and PK prepared photographs and contributed to the text.

Competing interests. The authors declare that they have no conflict of interest.

Acknowledgements. We thank Christian Klug (Universität Zürich, Switzerland) and René H. B. Fraaije (Oertijdmuseum, Netherlands) for their helpful review and the linguistic improvements made to our text. This is a contribution to IGCP 668 "Equatorial Gondwanan History and Early Palaeozoic Evolutionary Dynamics". We thank Martina Aubrechtová and Štěpán Manda (Czech Geological Survey, Prague) for determination of cephalopods and Marika Polechová (Czech Geological Survey, Prague) for determination of bivalves.

Financial support. This research was supported by the Czech Science Foundation (GACR) project no. 18-14575S and the Ministry of Education, Youth and Sports of the Czech Republic (PROGRES Q45) (to Oldřich Fatka and Petr Kraft).

Review statement. This paper was edited by Christian Klug and reviewed by René Fraaije and Christian Klug.

\section{References}

Aubrechtová, M.: A revision of the Ordovician cephalopod Bactrites sandbergeri Barrande: Systematic position and palaeobiogeography of Bactroceras, Geobios, 48, 193-211, https://doi.org/10.1016/j.geobios.2015.03.002, 2015.

Aubrechtová, M. and Turek V.: Lituitid cephalopods from the Middle Ordovician of Bohemia and their paleobiogeographic affinities, Bull. Geosci., 93, 401-417, https://doi.org/10.3140/bull.geosci.1707, 2018.

Babcock, L. E.: Trilobites in Paleozoic predator-prey systems, and their role in reorganization of Early Paleozoic ecosystems, in: Predator-prey interactions in the fossil record, edited by: Kelley, P. H., Kowalewski, M., and Hansen, T. A., Kluwer Academic Publisher, New York, 55-92, 2003.

Bambach, R. K.: Energetics in the global marine fauna: A connection between terrestrial diversification and change in the marine biosphere, Geobios-Lyon, 32, 131-144, https://doi.org/10.1016/S0016-6995(99)80025-4, 1999.

Barrande, J.: Note sur quelques nouveaux fossils de'couverts aux environs de la ville de Rokitzan dans le bassin silurien du centre de la Bohême, Bull. Soc. Géol. Fr. Ser. 2, 13, 32-538, 1856.

Barrande, J.: Systême silurien du centre de la Bohême, Ière Partie: Recherches paléontologiques. Vol. III. Classe des Mollusques, Ordre des Ptéropodes, Chez l'auteur et éditeur, Prague, Paris, 1179 pp. +16 pls, 1867.

Barrande, J.: Système Silurien du centre de la Bohême, Vol. I., Chez l'auteur et éditeur, Prague, Paris, I., 1-647, 1872.

Bertling, M.: Arachnostega n. ichnog. - burrowing traces in internal moulds of boring bivalves (late Jurassic, Northern Germany), Paläont. Z., 66, 177-185, 1982.

Boucot, A. J.: Evolutionary paleobiology of behavior and coevolution, Elsevier, London, 725 pp., 1990.

Boucot, A. J. and Poinar Jr., G. O.: Fossil behavior compendium, CRC Press, Boca Raton, 363 pp., 2010.

Brett, C. E.: Entombment of a trilobite within a closed brachiopod shell, J. Paleontol., 51, 1041-1045, 1977.

Brett, C. E.: Durophagous predation in Paleozoic marine benthic assemblages, in: Predator-prey interactions in the fossil record, edited by: Kelley, P. H., Kowalewski, M., and Hansen, T. A., Kluwer Academic Publisher, 401-432, 2003.

Brett, C. E. and Walker, S. E.: Predators and predation in Paleozoic marine environments, in The Fossil Record of Predation, edited by: Kowalewski, M. and Kelley, P. H., Palaeontological Society Special Papers, 8, 93-118, Cambridge University Press, 2002.

Brett, C. E., Zambito, J. J., Hunda, B. R., and Schindler, E.: Mid-Paleozoic trilobite Lagerstätten: models of diagenetically enhanced obrution deposits, Palaios, 27, 326-345, https://doi.org/10.2110/palo.2011.p11-040r, 2012.

Bruthansová, J.: The trilobite Family Illaenidae Hawle et Corda, 1847 from the Ordovician of the Prague Basin (Czech Republic), T. Roy. Soc. Edin-Earth., 93, 167-190, 2003.

Bruthansová, J.: Exuviation of selected Bohemian Ordovician trilobites, Spec. Pap. Palaeontol., 70, 293-308, 2004.

Bruthansová, J. and Budil, P.: Exuviation of the genus Placoparia Hawle et Corda, 1847 (Trilobita, Czech Republic, Prague Basin, Ordovician), INSUGEO, Ser. Correl. Geol., 17, 271-274, 2003.

Bruthansová, J., Fatka, O., Budil, P., and Král, J.: 200 years of trilobite research in the Czech Republic, in: Fabulous Fossils - 300 Years of Worldwide Research on Trilobites, edited by: Mikulic, 
M. G., Landing, E., and Kluessendorf, J., N. Y. State Mus. Bull., 507, 51-80, 2007.

Budil, P. and Fatka, O.: Frontal Auxiliary Impressions in Ordovician trilobite genus Dalmanitina Reed, 1905 (Barrandian area, Czech Republic), Bull. Geosci., in press, 2021.

Budil, P., Kraft, P., Kraft, J., and Fatka, O.: Faunal associations of the Šarka Formation (Middle Ordovician, Darriwilian, Prague Basin, Czech Republic), Acta Palaeontol. Sinica Suppl., 46, 6470, 2007.

Budil, P., Fatka, O., Zwanzig, M., and Rak, Š.: Two unique Middle Ordovician trilobites from the Prague Basin (Czech Republic), J. Natl. Mus. Nat. Hist., 179, 95-104, 2010.

Chatterton, B. D. E., Collins, D. H., and Ludvigsen, R.: Cryptic behaviour in trilobites: Cambrian and Silurian examples from Canada, and other related occurrences, Spec. Pap. Palaeontol., 70, 157-173, 2003.

Chatterton, B. D. E. and Fortey, R. A.: Linear cluster sof articulated trilobites from Lower Ordovician (Arenig) strata at Bini Tinzoulin, North Zagora, Southern Morocco, in: Advances in trilobite research, edited by: Rábano, I., Gozalo, R., and GarcíaBellido, D., Cuadernos del Museo Geominero, 9: Instituto Geológico y Minero de España, Madrid, 73-77, 2008.

Chlupáč, I.: Neptunian dykes in the Koněprusy Devonian. Geological and palaeontological observations, Věst. Čes. Geol. Úst., 71, 193-208, 1996.

Cocks, L. R. M. and Fortey, R. A.: Lower Palaeozoic facies and fauna around Gondwana, in Gondwana and Tethys, edited by: Audley-Charles, M. G. and Hallam, A., Geol. Soc. Lond. Spec. Publ., 37, 183-200, 1988.

Davis, R. A., Fraaye, R. H. B., and Holland, C. H.: Trilobites within nautiloid cephalopods, Lethaia, 34, 37-45, 2001.

Fatka, O. and Budil, P.: Sheltered gregarious behavior of Middle Ordovician harpetid trilobites, Palaios, 29, 495-500, https://doi.org/10.2110/palo.2013.031, 2014.

Fatka, O. and Kozák, V.: A new type of entombment of Peronopsis (Agnostida) in a hyolithid conch, Carnets Geol., 14, 191-198, 2014.

Fatka, O. and Szabad, M.: Agnostids entombed under exoskeletons of paradoxidid trilobites, N. Jb. Geol. Paläont. Abh., 259, 207215, https://doi.org/10.1127/0077-7749/2011/0115, 2011.

Fatka, O., Vokáč, V., Moravec, J., and Valent, M.: Agnostid entombed in a hyolith conch, Mem. Assoc. Austral. Palaeontol., 37, 481-489, 2009.

Fatka, O., Mikuláš, R., Szabad, M., Micka, V., and Valent, M.: Arachnostega Bertling, 1992 in Drumian (Cambrian) sediments of the Barrandian area (Czech Republic), Acta Geol. Polon., 61, 367-381, 2011.

Fatka, O., Budil, P., and David, M.: Digestive structures in Ordovician trilobites Colpocoryphe and Flexicalymene from the Barrandian area of Czech Republic, Est. J. Earth Sci., 64, 255-266, https://doi.org/10.3176/earth.2015.32, 2015.

Fatka, O., Budil, P., and Mikuláš, R.: Healed injury in a nektobenthic trilobite: "Octopus-like" predatory style in Middle Ordovican?, Geol. Croat., in press, 2021a.

Fatka, O., Budil, P., and Zicha, O.: Exoskeletal and eye repair in Dalmanitina socialis (Trilobita): Example of blastemal regeneration in Ordovician?, Int. J. Paleopathol., in press, 2021 b.

Fernández-Álvarez, F. Á., Machordom, A., García-Jiménez, R., Salinas-Zavala, C. A., and Villanueva, R.: Predatory flying squids are detritivores during their early planktonic life, Sci. Rep.-UK, 8, 3440, https://doi.org/10.1038/s41598-018-21501-y, 2018.

Flick, U. and Flick, H.: Unterkarbon-Trilobiten in Wohnkammern von Goniatiten - Fossilfalle oder Häutungsplatz?, Der Aufschluss, 60, 245-250, 2009.

Foerse, A. F.: Preliminary notes on Cincinnatian and Lexington fossils of Ohio, Indiana, Kentucky and Tennessee, Bulletin of the Scientific Laboratories of Denison University, 16, 15-87, 1910.

Fortey, R. A.: Early Ordovician trilobite communities, Fossils and Strata, 4, 339-360, 1975.

Fortey, R. A.: Pelagic trilobites as an example of deducing the life habits of extinct arthropods, T. Roy. Soc. Edin-Earth., 76, 219230, 1985.

Fortey, R. A. and Owens, R. M.: The Arenig Series in South Wales, Bull. Brit. Mus. Nat. Hist. Geol., 41, 69-307, 1987.

Fortey, R. A. and Owens, R. M.: Feeding habits in trilobites, Palaeontology, 42, 429-465, 1999.

Gutiérrez-Marco, J.-C., Sá, A. A., García-Bellido, D. C., Rábano, I., and Valério, M.: Giant trilobites and trilobite clusters from the Ordovician of Portugal, Geology, 37, 443-446, https://doi.org/10.1130/G25513A.1, 2009.

Gutiérrez-Marco, J.-C., Sá, A. A., García-Bellido, D. C., and Rábano, I.: The Bohemo-Iberian regional chronostratigraphical scale for the Ordovician System and palaeontological correlations within South Gondwana, Lethaia, 50, 258-295, https://doi.org/10.1111/let.12197, 2017.

Haldeman, S. S.: Supplement to number one of "A monograph of the Limniades, or freshwater univalve shells of North America", containing descriptions of apparently new animals in different classes, and the names and characters of the subgenera in Paludina and Anculosa, J. Dobson, Philadelphia, 3 pp., 1840.

Hammann, W.: Die Placopariinae (Trilobita, Cheirurina, Ordovizium), Senckenberg, Lethaea, 52, 53-75, 1971.

Havlíček, V.: Ordovician of Bohemia: development of the Prague Basin and its benthic communities, Sbor. Geol. Věd, Geol., 37, 103-136, 1982.

Havlíček, V.: Ordovician, in: Palaeozoic of the Barrandian, edited by: Chlupáč, I., Havlíček, V., Kříž, J., Kukal, Z., and Štorch, P., Czech Geological Survey, Prague, 149-164, 1998.

Havlíček, V. and Vaněk, J.: The biostratigraphy of the Ordovician of Bohemia, Sbor. Geol. Věd, Paleontol., 8, 7-69, 1966.

Hawle, I. and Corda, A. C. J.: Prodrom einer Monographie der böhmischen Trilobiten, Abh. Königl. Böhm. Ges. Wiss., 5, 119-292, 1847.

Hicks, H.: On the succession of the Ancient Rocks in the vicinity of St. David's, Q. J. Geol. Soc. Lond., 31, 167-95, 1875.

Horný, R. J.: Shell breakage and repair in explanate bellerophontoidean gastropods from the Middle Ordovician of Bohemia, Věst. Čes. Geol. Úst., 72, 157-168, 1997a.

Horný, R. J.: Shell breakage and repair in Sinuitopsis neglecta (Mollusca, Tergomya) from the Middle Ordovician of Bohemia, Čas. Nár. Muz., Ř. Př́rodověd., 166, 137-142, 1997b.

Hsieh, A. and Plotnick, R. E.: The representation of animal behaviour in the fossil record, Anim Behav., 169, 65-80, 2020.

Kelly, P. H., Kowalewski, M., and Hansen, T. A. (Eds.): Predatorprey interactions in the fossil record: Topics in Geobiology Series 20, Kluwer Academic Publisher, New York, 1-464, 2003.

Kettner, R. and Kodym, O.: New stratigraphy of the Barrandian, Čas. Mus. Král. Českého, 93, 47-55, 1919 (in Czech). 
Klompmaker, A. A. and Fraaije, R. H. B.: Animal behavior frozen in time: gregarious behavior of Early Jurassic Lobsters within an Ammonoid body chamber, PLoS ONE, 7, e31893, https://doi.org/10.1371/journal.pone.0031893, 2012.

Klug, C., Frey, L., Pohle, A., De Baets, K., and Korn, D.: Palaeozoic evolution of animal mouthparts, Bull. Geosci., 92, 439-442, https://doi.org/10.3140/bull.geosci.1648, 2017

Kraft, J.: Type specimens of fossils in the West-Bohemian Museum in Plzeň and in the Regional Museum of Dr. B. Horák in Rokycany. Part I - Trilobita, Folia musei rerum naturalium Bohemiae occidentalis, Geologica, 1, 1-11, 1972.

Kraft, J. and Kraft, P.: Graptolite biozones of the Bohemian Lower and Middle Ordovician and their historical development, J. Czech Geol. Soc., 44, 53-62, 1999.

Kraft, P., Kraft, J., and Prokop, R. J.: A possible hydroid from the Lower and Middle Ordovician of Bohemia, Alcheringa, 25, 143154, https://doi.org/10.1080/03115510108619101, 2001.

Kraft, P., Bruthansová, J., and Mikuláš, R.: Feeding traces related to shells from the Prague Basin, Czech Republic (Tremadocian to early Darriwilian, Ordovician), Palaeogeography, Palaeoclimatology, Palaeoecology, 537, 109399, 1-21, https://doi.org/10.1016/j.palaeo.2019.109399, 2020.

Kröger, B.: Size matters - Analysis of shell repair scars in endocerid cephalopods, Foss. Rec., 14, 109-118, https://doi.org/10.1002/mmng.201100001, 2011.

Kukal, Z.: Petrographical investigation of the Ordovician Šárka beds in the Barrandian area, Sbor. Ústřed. Úst. Geol., Odd. Geol., 27, 175-214, 1962 (in Czech, English summary).

Manda, Š.: Trocholites Conrad, 1838 (Nautiloidea, Tarphycerida) in the Middle Ordovician of the Prague Basin and its palaeobiogeographical significance, Bull. Geosci., 83, 327-334, https://doi.org/10.3140/bull.geosci.2008.03.327, 2008.

Marek, L.: The trilobite family Cyclopygidae Raymond in the Ordovician of Bohemia, Rozpr. Ústřed. Úst. Geol., 28, 1-84, 1961.

Mergl, M., Fatka, O., and Budil, P.: Lower and early Middle Ordovician trilobite associations of the Prague Basin (Perunica, Czech Republic), Acta Palaeontol. Sinica Suppl., 46, 320-327, 2007.

Mergl, M., Fatka, O., and Budil, P.: Lower and Middle Ordovician trilobite associations of Perunica: from shoreface endemicicty to offshore uniformity (Prague Basin, Czech Republic), in: Advances in trilobite research, edited by: Rábano, I., Gozalo, R., and García-Bellido, D., Cuadernos del Museo Geominero, 9: Instituto Geológico y Minero de España, Madrid, 275-282, 2008.

Mikuláš, R. and Slavíčková, J.: Trilobites and minute ovoid pellets in a burrow (Ordovician, Llanvirnian, Czech Republic), Ichnos, 8, 243-249, https://doi.org/10.1080/10420940109380191, 2001.

Mikulic, D. G.: Sheltered molting by trilobites, Geol. Soc. Amer., Boulder. Abstracts with Programs, 26, 55, 1994.

Nixon, M.: The feeding mechanisms and diets of cephalopods - Living and fossil, in: Cephalopods Present and Past, edited by: Wiedmann J. and Kullmann, J., 2nd International Cephalopod Symposium, E. Schweizerbart'sche Verlagsbuchhandlung, Stuttgart, Germany, 642-652, 1988.

Novák, O. P. in Perner, J. (Eds.): Trilobiti D-d1 $\gamma$ z okolí Pražského [Trilobites of D-d $1 \gamma$ from the surroundings of Prague], Palaeontologia Bohemiae, 9, 1-55, 1918 (in Czech).
Prantl, F. and Přibyl, A.: On the Bohemian representatives of the family Harpetidae (Hawle \& Corda), Rozpr. Ústřed. Úst. Geol., 18, 1-170, 1954 (in Czech, Russian and English summary).

Owens, R. M. and Servais, T.: The Ordovician of the Condroz Inlier, Belgium: Trilobites from the southeastern margin of Avalonia, Palaeogeogr. Palaeoecl., 245, 272-294, 2007.

Peder, A. E. H. and Feist, R.: Lower Devonian (Emsian) rugosa of the Izarne Formation, Montagne Noire, France, J. Paleontol., 72, 967-991, 1998.

Přibyl, A. and Vaněk, J.: Einige Trilobiten aus dem böhmischen Ordovizium, Věst. Ústřed. Úst. Geol., 43, 191-197, 1968.

Radwański, A., Kin, A., and Radwańska, U.: Queues of blind phacopid trilobites Trimerocephalus: A case of frozen behaviour of Early Famennian age from the Holy Cross Mountains, Central Poland, Acta Geol. Pol., 59, 459-481, 2009.

Rakociński, M.: Phenomenon of "sheltered preservation" - an overview and fossil examples from the Upper Devonian of Poland, Przeglad Geol., 57, 584-590, 2009.

Raymond, P. E.: Note on the names Amphion, Harpina and Platymetopus, Am. J. Sci., 19, 377-378, 1905.

Salter, J. W.: On the fossils of the Lingula-Flags or "Zone Primordiale", Quarterly Journal of the Geological Society of London, $15,551-555,1859$.

Schoenemann, B., Clarkson, E. N. K., and Hoyberget, M.: Traces of an ancient immune system - how an injured arthropod survived 465 million years ago, Sci. Rep.-UK, 7, 40330, https://doi.org/10.1038/srep40330, 2017.

Šnajdr, M.: Note on the regenerative ability of injured trilobites, Věst. Ústřed. Úst. Geol., 54, 171-173, 1979.

Struve, W.: Beitrage zur Kenntnis der Phacopacea (Trilobita) 1: Die Zeliszkellinae, Senckenbergiana lethaea, 39, 165-219, 1958.

Suzuki, Y. and Bergström, J.: Trilobite taphonomy and ecology in Upper Ordovician carbonate buildups in Dalarna, Sweden, Lethaia, 32, 159-172, https://doi.org/10.1080/11035890903452670, 1999.

Valent, M., Fatka, O., Micka, V., and Šinágl, M.: Hyoliths with entombed trilobites - cryptic behavior of trilobites?, in: Advances in trilobite research, edited by: Rábano, I., Gozalo, R., and García-Bellido, D., Cuadernos del Museo Geominero, 9: Instituto Geológico y Minero de España, Madrid, 411-413, 2008.

Vinn, O., Wilson, M. A., Zatoń, M., and Toom, U.: The trace fossil Arachnostega in the Ordovician of Estonia (Baltica), Palaeontol. Electron., 17, 1-9, 2014.

Vokáč, V., Hartl, F., David, M., Pavlovič, M., Doubrava, M., Kozák, V., and Grigar, L.: Notable findings of trilobites from the Ordovician (Dapingian-Sandbian) of the Prague Basin (Barrandian area, Czech Republic), Erica, 22, 141-157, 2015 (in Czech, English summary).

Vokáč, V., Hartl, F., Pavlovič, M., Beneš, P., Zicha, O., Grigar, L., Tichávek, F., and Henkl, L.: Remarkable new findings of Ordovician (Darriwillian - Sandbian) trilobites in the southwest part of the Prague Basin (Rokycany region, Czech Republic), Erica, 26, 67-93, 2019 (in Czech, English summary).

Wani, R.: How to recognize in situ fossil cephalopods: evidence from experiments with modern Nautilus, Lethaia, 40, 305-311, 2007. 